\title{
Uji Multilokasi Sepuluh Galur Padi Untuk Menghasilkan Varietas Unggul Baru
}

\section{Multilocation Test Ten Rice Strains To Produce New Superior Varieties}

\author{
Jaenudin Kartahadimaja ${ }^{1 *}$ Eka Erlinda Syuriani ${ }^{2 *}$ \\ ${ }^{1,2}$ Jurusan Budidaya Tanaman Pangan, Politeknik Negeri Lampung \\ *E-mail : jaenudinkartahadimaja@gmail.com, eka.erlindas@ polinela.ac.id
}

\begin{abstract}
Reduced productive rice fields to non-paddy fields, most possible extension of the national rice cultivation area to the suboptimal lands reaching \pm 91.9 million ha. Technology packages that can be applied include the use of new improved rice varieties through the assembling of varieties that have high yield potential, resistant to suboptimal soil stress. The objective of the research is to produce new superior rice varieties that are available in various environments. The study used a split-plot design, as the main plot is an environment consisting of rice paddies and gogo, as a subplot is the genotype of rice. The treatment in each environment is prepared using the Randomized Complete Block Design (RCBD). The treatment consisted of 10 new rice strains and four varieties as a comparison. Variables observed (1) plant height; (2) the maximum number of shoots; (3) number of productive shoots; (4) long panicle; (5) the number of grains per panicle; (6) the amount of grain content of each panicle; (7) the number of empty grains per panicle; (8) weight of 1000 grains of grain; (9) grain yield of each clump; (10) grain yield per hectare. Data were analyzed by variance if there was a difference between mean, median treatment, followed by Lsd test at 5\% level. The adaptability and yield stability of each strain was determined based on the value of the coefficient of diversity (KK) (Francis and Kenneberg, 1978) in Syukur et al., (2012). The results showed that seven new rice strains had adaptations both planted as upland rice and lowland rice, namely strains $B 3, B 4, F 2, F 3, H 1, H 4$, and L2.
\end{abstract}

Keywords: Multilocation test, rice strain

Disubmit : $\quad$ Diterima: Disetujui :

\section{PENDAHULUAN}

Padi atau beras merupakan bahan makanan pokok hampir seluruh rakyat Indonesia, dengan kebutuhan yang terus meningkat (Santosa et al., 2011; Budiono et al., 2014). Suryana et al. (2009), menyatakan bahwa pemenuhan kebutuhan pangan merupakan salah satu hak manusia yang paling asasi dan salah satu faktor penentu ketahanan nasional. Oleh karena itu kekurangan pangan secara meluas disuatu negara akan menyebabkan kerawanan ekonomi, sosial dan politik yang dapat menggoyahkan stabilitas.

Capaian produksi padi nasional sejak tahun 2011 sampai tahun 2014 selalu dibawah target. Dari target produksi tahun 2014 sebesar 73 juta ton hanya mampu tercapai 70,8 juta ton, bahkan terjadi penurunan produksi 0,5 juta ton dibandingkan dengan produksi tahun 2013. Penurunan produksi disebabkan karena 
terjadinya penurunan luas panen sebesar 37945 hektar dan penurunan produktivitas dari 5,52 ku.ha ${ }^{-1}$ menjadi 5,35 ku.ha- ${ }^{-1}$ (BPS, 2015).

Berbagai permasalahan di Indonesia yang berkaitan dengan penyediaan pangan yang selalu meningkat sesuai dengan penambahan jumlah penduduk adalah permintaan terhadap pangan lebih cepat dari pada penyediaannya, adanya konversi lahan sawah menjadi bukan sawah, terjadinya degradasi kesuburan lahan, terjadinya stagnasi pertumbuhan produktivitas karena peningkatan kapasitas genetik yang sudah stagnan ((Sobir, 2013); Hersanti \& Mugiono, 2006). Lahan-lahan subotimal yang luasnya mencapai $\pm 91,9$ juta hektar merupakan areal yang memungkinkan untuk dikembangkan sebagai perluasan areal tanaman padi. Lahan suboptimal memiliki karakteristik antara lain memiliki $\mathrm{pH}$ yang rendah atau masam, yang secara alamiah mempunyai produktivitas rendah karena seperti sifat fisika, kimia, dan biologi yang rendah. Pendekatan paling efisien dalam pemanfaatan lahan subotimal adalah penggunaan varietas yang toleran terhadap cekaman abiotik dan biotik (Sobir, 2013).

Kartahadimaja sejak tahun 2012 mulai merakit galur padi baru dengan menggunakan tiga tetua unggul lokal dan satu tetua varietas unggul nasioal. Masing-masing tetua memiliki karakter unggul yang berbeda, antara lain potensi hasil tinggi, tahan hama dan penyakit utama, memiliki kualitas beras yang baik. Saat ini telah dihasilkan 10 progeni $\mathrm{F}_{8}$ hasil persilangan masing-masing tetua yang menunjukkan karakter fenotipe unggul. Hasil uji pendahuluan menunjukkan potensi hasil yang tinggi, yaitu 6,6-9,8 ton.ha ${ }^{-1}$ gabah kering giling (Kartahadimaja et al., 2016).

Tujuan Penelitian adalah menguji 10 galur padi hasil rakitan baru untuk menghasilkan galur padi baru yang memiliki karakter potensi hasil tinggi, memiliki adaptasi yang baik dibeberapa zona agroekologi yang berbeda.

\section{METODE PENELITIAN}

Penelitian dilakukan di Kebun Percobaan Polieknik Negeri Lampung selama 7 bulan, yaitu Januari sampai Juni 2017. Penelitian dilakukan pada dua lingkungan berbeda, yaitu Menguji adaptabilitas dan produktivitas 10 galur padi baru pada lahan sawah sebagai padi sawah (lawland rice), dan lahan darat atau padi gogo (upland rice) pada ketinggian tempat \pm 100 meter di atas permukan laut.

Penelitian dirancang dengan menggunakan rancangan split plot, sebagai petak utama adalah lingkungan (sawah dan gogo), sebagai anak petak adalah galur. Penelitian di setiap lingkungan dilakukan dengan mengunakan Rancangan Kelompok Teracak Sempurna (RKTS). Sebagai Perlakuan terdiri dari 10 galur tanaman padi baru dan 4 varietas komersial sebagai pembanding, sehingga akan terdapat 14 satuan percobaan. Setiap perlakuan diulang tiga kali, sehingga akan terdapat 42 plot percobaan (42 satuan percobaan).

Pemupukan dilakukan dengan menggunakan dosis pupuk Urea $300 \mathrm{~kg}$ ha-1, TSP $100 \mathrm{~kg}$ ha-1, KCl $100 \mathrm{~kg}$ ha-1. Pupuk Urea diberikan tiga tahap, yaitu 1/3 dosis diberikan umur 1 minggu setelah tanam, 1/3 dosis umur 30 hari setelah tanam, dan 1/3 dosis umur 50 hari setelah tanam. TSP dan KCL diberikan sekaligus pada umur 1 minggu setelah tanam.

Setiap plot perlakuan dibuat dengan ukuran $1,5 \mathrm{~m}$ x $2 \mathrm{~m}$. Jarak tanam yang digunakan $25 \mathrm{~cm}$ dalam barisan dan $25 \mathrm{~cm}$ jarak antar barisan tanaman. Variabel yang diamati pada penelitian ini antara lain 1) Tinggi tanaman, (2) Jumlah tunas maksimum; (3) Umur tanaman mulai berbunga; (4) Jumlah tunas produktif setiap rumpun; (5) Rata-rata panjang malai; (6) Rata-rata jumlah gabah setiap malai; (7) Jumlah gabah isi setiap malai; (8) Jumlah gabah hampa setiap malai; (9) Hasil gabah setiap rumpun; (10) Rata-rata hasil gabah tiap hektar. Data hasil pengamatan dianalisis dengan sidik ragam. Jjika ada perbedaan dintara rata-rata nilai tengah perlakuan, dilanjutkan dengan uji BNT 5\%. 


\section{HASIL DAN PEMBAHASAN}

Hasil analisis ragam menunjukan bahwa faktor galur dan lingkungan berpengaruh terhadap semua variabel yang diamat, serta terjadi interaksi antara galur dengan lingkungan tumbuh terhadap semua variabel yang diamati (Tabel 1). Berdasarkan tabel 1, penampilan tinggi tanaman dan umur berbunga menghasilkan nilai koefisien keragaman(KK) yang sangat rendah yaitu lebih kecil dari 5\%. Menurut Hallauer dan Miranda (1981), Koefisien Keragaman (KK) yang lebih kecil dari 5\% dianggap bahwa fenotipe merupakan ekspresi genotipe $(F=G+I ; I=0$,. Koefisien keragaman yang lebih kecil atau sama dengan 5\% menunjukkan fenotipik sama dengan genotipik $(F=G)$. Koefisien keragaman yang melampaui $10 \%$ menunjukkan bahwa pengaruh lingkungan atas kinerja fenotipe yang tidak dapat diabaikan. Artinya pengaruh lingkungan terhadap penampilan karakter fenotifik suatu tanaman lebih besar dipengaruhi oleh faktor lingkungan.

Adaptabilitas dan stabilitas suatu genotipe sangat dipengaruhi oleh kondisi lingkungannya (Rahayu et al., 2013). Melalui interaksi genotipe dengan lingkungan stabilitas penampilan genotipe pada suatu kisaran lingkungan dapat diukur. Metode yang dapat digunakan dalam menduga adaptabilitas dan stabilitas fenotipik seperti hasil antara lain melalui pengujian berulang pada berbagai lingkungan tumbuh yang bervariasi (Singh \& Chaudhary, 1979).

Tabel 1. Pengaruh Galur dan lingkungan terhadap beberapa variabel yang diamati

\begin{tabular}{llclclc}
\hline No & Variabel & Galur & KK $(\%)$ & Lingkungan & KK $(\%)$ & GxL \\
\hline 1 & Tinggi Tanaman & $*$ & 2,92 & $*$ & 3,63 & $*$ \\
2 & Jumlah Tunas Maksimum & $*$ & 16,76 & $*$ & 8,21 & $*$ \\
3 & Jumlah Tunas Produktif & $*$ & 18,48 & $*$ & 27,12 & $*$ \\
4 & Umur berbunga & $*$ & 2,34 & $*$ & 3,82 & $*$ \\
5 & Panjang malai & $*$ & 2,79 & $*$ & 5,32 & $*$ \\
6 & Jumlah gabah tiap malai & $*$ & 10,16 & $*$ & 21,40 & $*$ \\
7 & Jumlah gabah isi tiap malai & $*$ & 13,61 & $*$ & 15,64 & $*$ \\
8 & Jumlah gabah hampa tiap malai & $*$ & 28,12 & $*$ & 26,75 & $*$ \\
9 & Bobo 1000 butir gabah & $*$ & 6,18 & $*$ & 6,21 & $*$ \\
10 & Hasil gabah tiap rumpun & $*$ & 21,32 & $*$ & 31,95 & $*$ \\
11 & Hasil gabah tiap hektar & $*$ & 21,32 & $*$ & 31,95 & $*$ \\
\hline
\end{tabular}

Keterangan:

$$
\begin{array}{ll}
\mathrm{G} & : \text { galur } \\
\mathrm{L} & : \text { Lingkunga tumbuh } \\
\mathrm{G} \times \mathrm{L} & : \text { Interaksi antara galur dengan lingkungan } \\
* & : \text { berpengaruh nyata }
\end{array}
$$

\section{Tinggi Tanaman dan Jumlah Tunas Maksimum}

Hasil penenelitian menunjukan, bahwa terjadi interaksi antara lingkungan dan galur terhadap tinggi tanaman dan jumlah tunas maksimum (Tabel 2). Lingkungan sawah memiliki pengaruh yang lebih cocok terhadap variabel tinggi tanaman dan pertumbuhan tunas maksimum. Hanya ada satu galur, yaitu galur B2 yang pertumbuhan tinggi tanamannya stabil pada saat ditanam di lahan kering atau gogo (upland rice) dan sawah (low land rice). Varietas Inpago-8 merupaka genotipe tanaman yang memiliki tinggi tanaman yang paling tingi pada lingkungan lahan sawah dibanding genotipe lain, sedangkan genotipe yang tinggi tanamannya paling pendek adalah genotipe $\mathrm{H} 1$. 
Tabel 2. Interaksi Galur dan Lingkungan terhadap tinggi tanaman dan jumlah tunas produktif

\begin{tabular}{|c|c|c|c|c|}
\hline \multirow[t]{2}{*}{ Galur } & \multicolumn{2}{|c|}{ Tinggi Tanaman $(\mathrm{cm})$} & \multicolumn{2}{|c|}{$\begin{array}{l}\text { Jumlah Tunas Maksimum } \\
\text { (batang) }\end{array}$} \\
\hline & Gogo & Sawah & Gogo & Sawah \\
\hline B2 & $\begin{array}{l}105,9 \mathrm{f} \\
\text { (a) }\end{array}$ & $\begin{array}{l}108,0 \mathrm{fg} \\
\text { (a) }\end{array}$ & $\begin{array}{l}9,3 \mathrm{a} \\
\text { (b) }\end{array}$ & $\begin{array}{l}34,0 \mathrm{a} \\
\text { (a) }\end{array}$ \\
\hline B3 & $\begin{array}{l}118,9 \mathrm{c} \\
\text { (b) }\end{array}$ & $\begin{array}{l}136,7 \mathrm{c} \\
\text { (a) }\end{array}$ & $\begin{array}{l}8,3 \mathrm{a} \\
\text { (b) }\end{array}$ & $\begin{array}{l}33,7 \mathrm{a} \\
\text { (a) }\end{array}$ \\
\hline B4 & $\begin{array}{l}93,9 \mathrm{~h} \\
\text { (b) }\end{array}$ & $\begin{array}{l}101,2 \mathrm{~h} \\
\text { (a) }\end{array}$ & $\begin{array}{l}7,9 \mathrm{a} \\
\text { (b) }\end{array}$ & $\begin{array}{l}33,2 \mathrm{ab} \\
\text { (a) }\end{array}$ \\
\hline B7 & $\begin{array}{l}96,0 \mathrm{gh} \\
\text { (b) }\end{array}$ & $\begin{array}{l}110,3 \mathrm{f} \\
\text { (a) }\end{array}$ & $\begin{array}{l}8,3 \mathrm{a} \\
\text { (b) }\end{array}$ & $\begin{array}{l}26,6 \mathrm{c} \\
\text { (a) }\end{array}$ \\
\hline $\mathrm{F} 2$ & $\begin{array}{l}118,4 \mathrm{c} \\
\text { (b) }\end{array}$ & $\begin{array}{l}139,0 \mathrm{c} \\
\text { (a) }\end{array}$ & $\begin{array}{l}6,0 \mathrm{a} \\
\text { (b) }\end{array}$ & $\begin{array}{l}27,0 \mathrm{c} \\
\text { (a) }\end{array}$ \\
\hline F3 & $\begin{array}{l}96,4 \mathrm{gh} \\
\text { (b) }\end{array}$ & $\begin{array}{l}113,8 \mathrm{e} \\
\text { (a) }\end{array}$ & $\begin{array}{l}8,5 \mathrm{a} \\
\text { (b) }\end{array}$ & $\begin{array}{l}28,1 \mathrm{c} \\
\text { (a) }\end{array}$ \\
\hline F4 & $\begin{array}{l}126,9 \mathrm{~b} \\
\text { (b) }\end{array}$ & $\begin{array}{l}143,0 \mathrm{~b} \\
\text { (a) }\end{array}$ & $\begin{array}{l}6,0 \mathrm{a} \\
\text { (b) }\end{array}$ & $\begin{array}{l}33,9 \mathrm{a} \\
\text { (a) }\end{array}$ \\
\hline H1 & $\begin{array}{l}90,3 \mathrm{i} \\
\text { (b) }\end{array}$ & $\begin{array}{l}105,2 \mathrm{~g} \\
\text { (a) }\end{array}$ & $\begin{array}{l}8,7 \mathrm{a} \\
\text { (b) }\end{array}$ & $\begin{array}{l}29,1 \mathrm{bc} \\
\text { (a) }\end{array}$ \\
\hline $\mathrm{H} 4$ & $\begin{array}{l}97,1 \mathrm{~g} \\
\text { (b) }\end{array}$ & $\begin{array}{l}108,7 \mathrm{f} \\
\text { (a) }\end{array}$ & $\begin{array}{l}8,0 \mathrm{a} \\
\text { (b) }\end{array}$ & $\begin{array}{l}29,2 \mathrm{bc} \\
\text { (a) }\end{array}$ \\
\hline L2 & $\begin{array}{l}111,0 \mathrm{e} \\
\text { (b) }\end{array}$ & $\begin{array}{l}123,0 \mathrm{~d} \\
\text { (a) }\end{array}$ & $\begin{array}{l}8,4 \mathrm{a} \\
\text { (b) }\end{array}$ & $\begin{array}{l}33,0 \mathrm{ab} \\
\text { (a) }\end{array}$ \\
\hline Inpago 8 & $\begin{array}{l}130,9 \mathrm{a} \\
\text { (b) }\end{array}$ & $\begin{array}{l}156,7 \mathrm{a} \\
\text { (a) }\end{array}$ & $\begin{array}{l}5,5 \mathrm{a} \\
\text { (b) }\end{array}$ & $\begin{array}{l}20,8 \mathrm{~d} \\
\text { (a) }\end{array}$ \\
\hline P. Wangi & $\begin{array}{l}128,8 \mathrm{ab} \\
\text { (b) }\end{array}$ & $\begin{array}{l}138,1 \mathrm{c} \\
\text { (a) }\end{array}$ & $\begin{array}{l}8,5 \mathrm{a} \\
\text { (b) }\end{array}$ & $\begin{array}{l}34,3 \mathrm{a} \\
\text { (a) }\end{array}$ \\
\hline Gilirang & $\begin{array}{l}115,4 \mathrm{~d} \\
\text { (b) }\end{array}$ & $\begin{array}{l}122,6 \mathrm{~d} \\
\text { (a) }\end{array}$ & $\begin{array}{l}7,2 \mathrm{a} \\
\text { (b) }\end{array}$ & $\begin{array}{l}21,3 \mathrm{~d} \\
\text { (a) }\end{array}$ \\
\hline Ciherang & $\begin{array}{l}97,8 \mathrm{~g} \\
\text { (b) }\end{array}$ & $\begin{array}{l}120,6 \mathrm{~d} \\
\text { (a) }\end{array}$ & $\begin{array}{l}5,9 \text { a } \\
\text { (b) }\end{array}$ & $\begin{array}{l}30,7 \mathrm{abc} \\
\text { (a) }\end{array}$ \\
\hline
\end{tabular}

Keterangan: Angka-angka yang diikuti huruf yang sama tanpa kurung pada kolom yang sama menunjukkan tidak berbeda nyata, dan angka-angka yang diikuti huruf yang sama dalam kurung pada baris yang sama menunjukkan tidak berbeda nyata menurut uji BNT 5\%.

Menurut Makarim \& Suhartatik (2009), hasil tanaman padi yang tinggi harus didikung dengan batang yang kokoh. Bila tidak, tanaman akan rebah terutama di daerah yang sering dilanda angin kencang. Batang yang pendek dan kaku merupakan sifat yang dikehendaki dalam pengembangan varietas-varietas unggul padi karena tanamaan menjadi tahana rebah, perbandingan antara gabah dengan jerami lebih seimbang, dan tanggap terhadap pemupukan nitrogen.

Kemampuan genotipe padi yang diuji untuk menghasilkan jumlah tunas maksimum pada lingkungan sawah dan gogo berbeda. Pada lingkungan sawah semua galur baru mampu menghasilkan tunas yang lebih banyak dibandingkan pada lingkungan gogo. Galur yang ditanam di sawah mampu menghasilkan tunas atau anakan paling sedikit 26,6 dan tertinggi 34,0. Galur yang ditanam sebagai padi gogo hanya mampu menghasilkan tunas atau anakan antara 6,0-9,3. Kemampuan galur padi baru dan varietas pembanding dalam menghasilkan tunas atau anakan maksimum pada lingkungan sawah termasuk katagori mampu menghasilkan tuas yang banyak, sedangkan pada lingkungan gogo termasuk sedikit. Berdasarkan besaran nilai Koefisien Keragaman (KK) tinggi tanaman dan jumlah tunas maksimum yang relatif rendan ini menunjukkan bahwa faktor genotipe lebih punya kendali dibandingkan lingkungan. Genotipe padi di atas lebih cocok sebagai padi sawah. 


\section{Jumlah Tunas Produktif dan Umur Berbunga}

Pertumbuhan jumlah tunas produktif pada lingkungan lahan sawah lebih baik atau lebih banyak dibandingkan pada lingkungan lahan kering atau gogo. Jumlah tunas produktif merupakan salah satu komponen penentu produksi padi dalam luasan lahan tertentu yang erat hubungannya dengan banyaknya gabah yang dihasilkan. tunas produktif merupakan tunas yang mampu menghasilkan malai. Semakin banyak malai yang dihasilkan dari setiap rumpun tanaman padi, peluang untuk menghasilkan gabah padi akan semakin banyak (Fatimaturrohmah et al., 2016). (Abdullah, 2006), menyatakan bahwa tipe tanaman padi yang bernak banyak dapat mengakibatkan rendahnya indeks panen dan rendahnya kualitas beras. Dengan anakan yang banyak, tidak semua anakan menghasilkan malai dan atau tidak semua malai masak bersamaan, akibatnya kualitas beras rendah karenabanyak butir hijau.

Tabel 3. Interaksi Galur dan Lingkungan terhadap jumlah tunas produktif dan umur berbunga

\begin{tabular}{|c|c|c|c|c|}
\hline \multirow{2}{*}{ Galur } & \multicolumn{2}{|c|}{ Jumlah Tunas Produktif (btg) } & \multicolumn{2}{|c|}{ Umur Berbunga (hari) } \\
\hline & Gogo & Sawah & Gogo & Sawah \\
\hline B2 & $\begin{array}{l}5,2 \text { bcd } \\
\text { (b) }\end{array}$ & $\begin{array}{c}22,7 \text { a } \\
\text { (a) }\end{array}$ & $\begin{array}{c}81,3 \mathrm{~d} \\
\text { (a) }\end{array}$ & $\begin{array}{c}80,0 \text { e } \\
\text { (a) }\end{array}$ \\
\hline B3 & $\begin{array}{c}6,0 \text { abc } \\
\text { (b) }\end{array}$ & $\begin{array}{c}14,6 \mathrm{~g} \\
\text { (a) }\end{array}$ & $\begin{array}{c}77,0 \mathrm{~g} \\
\text { (b) }\end{array}$ & $\begin{array}{c}84,1 \mathrm{c} \\
\text { (a) }\end{array}$ \\
\hline B4 & $\begin{array}{l}6,1 \mathrm{abc} \\
\text { (b) }\end{array}$ & $\begin{array}{c}16,2 \text { ef } \\
\text { (a) }\end{array}$ & $\begin{array}{c}79,3 \text { ef } \\
\text { (a) }\end{array}$ & $\begin{array}{c}78,8 \text { ef } \\
\text { (a) }\end{array}$ \\
\hline B7 & $\begin{array}{l}6,9 \mathrm{a} \\
\text { (b) }\end{array}$ & $\begin{array}{l}18,3 \mathrm{~cd} \\
\text { (a) }\end{array}$ & $\begin{array}{c}80,3 \text { de } \\
\text { (b) }\end{array}$ & $\begin{array}{c}85,0 \text { bc } \\
\text { (a) }\end{array}$ \\
\hline F2 & $\begin{array}{l}4,8 \mathrm{~cd} \\
\text { (b) }\end{array}$ & $\begin{array}{l}17,7 \text { de } \\
\text { (a) }\end{array}$ & $\begin{array}{l}87,8 \text { b } \\
\text { (a) }\end{array}$ & $\begin{array}{c}86,0 \text { b } \\
\text { (a) }\end{array}$ \\
\hline F3 & $\begin{array}{l}7,0 \mathrm{a} \\
\text { (b) }\end{array}$ & $\begin{array}{l}20,7 \mathrm{~b} \\
\text { (a) }\end{array}$ & $\begin{array}{l}78,7 \mathrm{f} \\
\text { (b) }\end{array}$ & $\begin{array}{c}82,4 \mathrm{~d} \\
\text { (a) }\end{array}$ \\
\hline F4 & $\begin{array}{l}4,2 \mathrm{~d} \\
\text { (b) }\end{array}$ & $\begin{array}{l}19,4 \mathrm{bc} \\
\text { (a) }\end{array}$ & $\begin{array}{l}81,0 \mathrm{~d} \\
\text { (b) }\end{array}$ & $\begin{array}{c}91,0 \mathrm{a} \\
\text { (a) }\end{array}$ \\
\hline H1 & $\begin{array}{l}5,2 \text { bcd } \\
\text { (b) }\end{array}$ & $\begin{array}{l}15,1 \mathrm{fg} \\
\text { (a) }\end{array}$ & $\begin{array}{c}84,9 \mathrm{c} \\
\text { (a) }\end{array}$ & $\begin{array}{c}78,1 \mathrm{f} \\
\text { (b) }\end{array}$ \\
\hline $\mathrm{H} 4$ & $\begin{array}{c}5,8 \mathrm{abc} \\
\text { (b) }\end{array}$ & $\begin{array}{c}17,8 \text { de } \\
\text { (a) }\end{array}$ & $\begin{array}{l}80,0 \text { def } \\
\text { (b) }\end{array}$ & $\begin{array}{c}84,0 \mathrm{c} \\
\text { (a) }\end{array}$ \\
\hline L2 & $\begin{array}{l}6,7 \mathrm{ab} \\
\text { (b) }\end{array}$ & $\begin{array}{l}19,1 \mathrm{~cd} \\
\text { (a) }\end{array}$ & $\begin{array}{c}80,9 \mathrm{~d} \\
\text { (b) }\end{array}$ & $\begin{array}{c}91,0 \mathrm{a} \\
\text { (a) }\end{array}$ \\
\hline Inpago 8 & $\begin{array}{l}4,7 \mathrm{~cd} \\
\text { (b) }\end{array}$ & $\begin{array}{c}12,2 \mathrm{~h} \\
\text { (a) }\end{array}$ & $\begin{array}{l}88,2 \text { ab } \\
\text { (b) }\end{array}$ & $\begin{array}{c}91,8 \mathrm{a} \\
\text { (a) }\end{array}$ \\
\hline P. Wangi & $\begin{array}{l}6,6 \mathrm{ab} \\
\text { (b) }\end{array}$ & $\begin{array}{l}18,2 \mathrm{~cd} \\
\text { (a) }\end{array}$ & $\begin{array}{c}79,2 \text { ef } \\
\text { (b) }\end{array}$ & $\begin{array}{c}85,7 \text { b } \\
\text { (a) }\end{array}$ \\
\hline Gilirang & $\begin{array}{l}4,6 \mathrm{~cd} \\
\text { (b) }\end{array}$ & $\begin{array}{c}14,1 \mathrm{~g} \\
\text { (a) }\end{array}$ & $\begin{array}{c}89,4 \text { a } \\
\text { (a) }\end{array}$ & $\begin{array}{c}91,1 \text { a } \\
\text { (a) }\end{array}$ \\
\hline Ciherang & $\begin{array}{l}4,2 \mathrm{~d} \\
\text { (b) }\end{array}$ & $\begin{array}{c}18,0 \mathrm{~cd} \\
\text { (a) }\end{array}$ & $\begin{array}{l}80,6 \text { de } \\
\text { (b) }\end{array}$ & $\begin{array}{c}84,9 \text { bc } \\
\text { (a) }\end{array}$ \\
\hline
\end{tabular}

Secara keseluruhan, genotipe padi yang diuji pada dua lingkungan tanam yang berbeda, yaitu di lahan sawah dan gogo, menunjukkan bahwa jumlah tunas produktif yang dihasilkan pada lingkungan sawah lebih banyak dibandingkan yang ditanam pada lahan gogo. Berdasarkan tabel 1 , variabel jumlah tunas produktif 
memiliki KK yang tinggi, yaitu 27,12\%. Koefisien Keragaman (KK) yang melampaui $10 \%$ menunjukkan bahwa pengaruh lingkungan atas kinerja fenotipe yang tidak dapat diabaikan (Hallauer \& Miranda, 1981).

Pengaruh lingkungan terhadap umur berbunga, galur padi yang diuji terdapat tiga galur padi baru dan satu varietas pembanding yang stabil penampilannya jika ditanam pada dua lingkungan berbeda, yaitu galur B2, B4, F2, dan varietas Gilirang. Galur dan varietas yang lain mengalami perbedaan terhadap waktu pembungaan (Tabel 3). Nilai KK untuk galur dan Lingkungan pada variabel umur berbunga sangat rendah, yaitu masing-masing 2,3 dan 3,8. Ini menunjukkan bahwa variabel umur berbunga lebih dikendalikan oleh faktor genetik (Hallauer \& Miranda, 1981).

\section{Panjang Malai dan Jumlah Gabah tiap Malai}

Interaksi Galur dan Lingkungan terhadap ukuran panjang malai, semua galur dan varietas pembanding menunjukkan bahwa ukuran panjang malai di lahan sawah (lawland rice) lebih baik dibandingkan dilahan kering atau gogo (Tabel 4).

Tabel 4. Interaksi Galur dan Lingkungan terhadap panjang malai dan jumlah gabah tiap malai

\begin{tabular}{|c|c|c|c|c|}
\hline \multirow{2}{*}{ Galur } & \multicolumn{2}{|c|}{ Panjang Malai $(\mathrm{cm})$} & \multicolumn{2}{|c|}{ Jumlah Gabah Tiap Malai (butir) } \\
\hline & Gogo & Sawah & Gogo & Sawah \\
\hline & $23,2 \mathrm{~d}$ & $25,2 \mathrm{e}$ & $125,2 \mathrm{gh}$ & $149,3 \mathrm{f}$ \\
\hline B2 & (b) & (a) & (a) & (a) \\
\hline & $23,8 \mathrm{c}$ & $27,7 \mathrm{c}$ & $195,2 \mathrm{a}$ & $197,7 \mathrm{~b}$ \\
\hline B3 & (b) & (a) & (a) & (a) \\
\hline B4 & $\begin{array}{l}22,4 \mathrm{fg} \\
\text { (b) }\end{array}$ & $\begin{array}{c}23,9 \mathrm{~g} \\
\text { (a) }\end{array}$ & $\begin{array}{c}146,6 \text { bc } \\
\text { (a) }\end{array}$ & $\begin{array}{c}139,8 \mathrm{~g} \\
\text { (a) }\end{array}$ \\
\hline & $22,2 \mathrm{~g}$ & $26,3 \mathrm{~d}$ & $122,9 \mathrm{gh}$ & $161,5 \mathrm{de}$ \\
\hline B7 & (b) & (a) & (b) & (a) \\
\hline $\mathrm{F} 2$ & $\begin{array}{c}22,6 \mathrm{fg} \\
\text { (b) }\end{array}$ & $\begin{array}{c}27,3 \mathrm{c} \\
\text { (a) }\end{array}$ & $\begin{array}{c}117,4 \mathrm{~h} \\
\text { (a) }\end{array}$ & $\begin{array}{c}125,1 \mathrm{~h} \\
\text { (a) }\end{array}$ \\
\hline F3 & $\begin{array}{c}23,1 \mathrm{de} \\
\text { (b) }\end{array}$ & $\begin{array}{c}25,9 \mathrm{~d} \\
\text { (a) }\end{array}$ & $\begin{array}{c}127,0 \mathrm{fg} \\
\text { (a) }\end{array}$ & $\begin{array}{c}138,3 \mathrm{~g} \\
\text { (a) }\end{array}$ \\
\hline F4 & $\begin{array}{c}25,4 \mathrm{a} \\
\text { (b) }\end{array}$ & $\begin{array}{c}27,7 \mathrm{c} \\
\text { (a) }\end{array}$ & $\begin{array}{c}143,8 \text { bcd } \\
\text { (a) }\end{array}$ & $\begin{array}{c}165,0 \mathrm{~d} \\
\text { (a) }\end{array}$ \\
\hline H1 & $\begin{array}{l}20,0 \mathrm{j} \\
\text { (b) }\end{array}$ & $\begin{array}{c}24,8 \text { ef } \\
\text { (a) }\end{array}$ & $\begin{array}{l}126,3 \text { fgh } \\
\text { (b) }\end{array}$ & $\begin{array}{l}154,3 \text { ef } \\
\text { (a) }\end{array}$ \\
\hline $\mathrm{H} 4$ & $\begin{array}{c}22,8 \text { ef } \\
\text { (b) }\end{array}$ & $\begin{array}{c}24,5 \mathrm{f} \\
\text { (a) }\end{array}$ & $\begin{array}{l}136,6 \text { de } \\
\text { (a) }\end{array}$ & $\begin{array}{c}136,0 \mathrm{~g} \\
\text { (a) }\end{array}$ \\
\hline & $25,4 \mathrm{a}$ & $28,3 \mathrm{~b}$ & $123,8 \mathrm{gh}$ & $138,6 \mathrm{~g}$ \\
\hline L2 & (b) & (a) & (a) & (a) \\
\hline Inpago 8 & $\begin{array}{c}23,8 \mathrm{c} \\
\text { (b) }\end{array}$ & $\begin{array}{l}31,0 \mathrm{a} \\
\text { (a) }\end{array}$ & $\begin{array}{c}149,3 \mathrm{~b} \\
\text { (b) }\end{array}$ & $\begin{array}{c}223,0 \mathrm{a} \\
\text { (a) }\end{array}$ \\
\hline & $24,4 b$ & $28,5 \mathrm{~b}$ & 134,4 def & $179,9 \mathrm{c}$ \\
\hline P. Wangi & (b) & (a) & (b) & (a) \\
\hline Gilirang & $\begin{array}{c}20,5 \mathrm{i} \\
\text { (b) }\end{array}$ & $\begin{array}{c}23,8 \mathrm{~g} \\
\text { (a) }\end{array}$ & $\begin{array}{c}138,6 \text { cde } \\
\text { (b) }\end{array}$ & $\begin{array}{c}178,1 \mathrm{c} \\
\text { (a) }\end{array}$ \\
\hline Ciherang & $\begin{array}{l}21,1 \mathrm{~h} \\
\text { (b) }\end{array}$ & $\begin{array}{c}26,0 \mathrm{~d} \\
\text { (a) }\end{array}$ & $\begin{array}{c}112,5 \mathrm{i} \\
\text { (b) }\end{array}$ & $\begin{array}{c}156,2 \text { def } \\
\text { (a) }\end{array}$ \\
\hline
\end{tabular}

Keterangan: Angka-angka yang diikuti huruf yang sama tanpa kurung pada kolom yang sama menunjukkan tidak berbeda nyata, dan angka-angka yang diikuti huruf yang sama dalam kurung pada baris yang sama menunjukkan tidak berbedanyata menurut uji BNT 5\%. 
Pada lingkungan lahan kering atau gogo (upland rice), galur F4 dan L2 merupakan dua galur padi baru yang memiliki panjang malai lebih panjang dibandingkan galur lain dan varietas pembanding. Malai yang terpendek dihasilkan oleh galur $\mathrm{H} 1$.

Interaksi Galur dan Lingkungan terhadap ukuran panjang malai, semua galur dan varietas pembanding menunjukkan bahwa ukuran panjang malai di lahan sawah (lawland rice) lebih baik dibandingkan dilahan kering atau gogo (Tabel 4). Pada lingkungan lahan kering atau gogo (upland rice), galur F4 dan L2 merupakan dua galur padi baru yang memiliki panjang malai lebih panjang dibandingkan galur lain dan varietas pembanding. Malai yang terpendek dihasilkan oleh galur $\mathrm{H} 1$.

Karakter panjang malai berkaitan erat dengan jumlah gabah yang ada pada malai (Fatimaturrohmah et al., 2016); (Mahmud \& Purnomo, 2014). Kemampuan tanaman untuk menghasilkan jumlah gabah permalai dipengaruhi oleh berbagai faktor, salah satu faktor diantaranya adalah panjang malai. Malai padi yang panjang memiliki kecenderungan menghasilkan jumlah gabah yang lebih banyak.

Varietas Inpago-8 yang ditanam pada lingkungan sawah memiliki panjang malai yang paling panjang dan memiliki jumlah gabah tiap malai yang lebih banyak, sedangkan yang terpedek adalah varietas gilirang dan galur B4. Interaksi Galur dan Lingkungan terhadap jumlah gabah tiap malai, terdapat tujuh galur yang memiliki kemampuan adaptasi yang stabil, yaitu galur B2, B3, B4, F2, F3, H4, dan L2. Galur-galur tersebut memiliki panjang malai dan menghasilkan jumlah bagah tiap malai yang konsisten tidak berbeda nyata baik di tanam di lahan sawah maupun ditanam di lahan gogo. Galur dan varietas yang yang lain menunjukkan penampilan yang tidak stabil (Tabel 4). Keragaan Tanaman dipengaruhi oleh faktor genetik dan lingkungan serta interaksi keduanya (Trustinah dan Iswanto, 2013).

Pada lingkungan lahan kering (upland rice), galur B3 merupakan galur yang memiliki potensi menghasilkan jumlah gabah tiap malai paling banyak dan stabil dengan jika ditanam sebagai padi sawah. Genotipe yang menghasilkan jumlah gabah paling sedikit adalah varietas Ciherang. Varietas Inpago 8 yang sebenarnya adalah varietas padi gogo, ternyata potensi untuk menghasilkan jumlah gabah tiap malai lebih tinggi pada saat genotipe tersebut ditanam sebagai padi sawah. Ini merupakan hal yang menarik, dan ternyata masih mudah terpengaruh oleh keadaan lingkungan. Genotipe yang menghasilkan jumlah gabah tiap malai terendah pada lingkungan sawah adalah galur F2.

\section{Jumlah Gabah isi dan Gabah Hampa tiap Malai}

Interaksi Galur dan Lingkungan terhadap jumlah gabah isi (Tabel 5), menunjukkan terdapat dua galur padi baru yaitu galur B4, dan H4 yang jumlah gabahnya stabil pada saat ditanam pada lingkungan yang berbeda (lahan kering atau gogo dan sawah), sedangkan galur lain dan varietas pembanding mengalami perbedaan. Pada lingkungan lahan kering atau gogo, galur B3, merupakan galur yang memiliki potensi menghasilkan gabah isi tiap malai paling banyak, sedangkan di lingkungan sawah yang paling banyak adalah B3 dan Inpago 8. Nilai Koefisien Keragaman (KK) untuk variabel jumlah gabah isi dan hampa untuk genotipe dan lingkungan lebih besar dari 13\%. Kondisi ini menunjukkan bahwa variabel jumlah gabah isi dan jumlah gabah hampa lebih dikendalikan oleh faktor lingkungan (Hallauer \& Miranda, 1981). Hanya ada dua galur yang jumlah gabah isi dan gabah hampanya stabil pada lingkungan sawah dan gogo, yaitu galur B4 dan $\mathrm{H} 4$.

Interaksi Galur dan Lingkungan terhadap jumlah gabah hampa, galur H4, L2, F3, dan varietas Ciherang menunjukkan penampilan yang stabil (Tabel 5), yaitu ditujukkan oleh jumlah gabah hampa pada lahan kering atau gogo dan di lahan basah atau sawah, jumlah gabah hampanya tidak berbeda nyata. 
Tabel 5. Interaksi Galur dan Lingkungan terhadap jumlah gabah isi dan gabah Hampa tiap malai

\begin{tabular}{|c|c|c|c|c|}
\hline \multirow{2}{*}{ Galur } & \multicolumn{2}{|c|}{ Jumlah Gabah Isi/malai (btg) } & \multicolumn{2}{|c|}{ Jumlah Gabah Hampa/malai (hari) } \\
\hline & Gogo & Sawah & Gogo & Sawah \\
\hline & 70,7 ef & $135,2 \mathrm{~cd}$ & $54,5 \mathrm{~b}$ & 14,3 efg \\
\hline B2 & (b) & (a) & (a) & (b) \\
\hline & $146,0 \mathrm{a}$ & $183,5 \mathrm{a}$ & 49,2 bc & $14,2 \mathrm{fg}$ \\
\hline B3 & (b) & (a) & (a) & (b) \\
\hline B4 & $\begin{array}{c}103,2 \text { bc } \\
\text { (a) }\end{array}$ & $\begin{array}{c}119,1 \text { ef } \\
\text { (a) }\end{array}$ & $\begin{array}{c}43,4 \text { cde } \\
\text { (a) }\end{array}$ & $\begin{array}{c}21,6 \mathrm{cdef} \\
\text { (b) }\end{array}$ \\
\hline B7 & $\begin{array}{l}85,9 \mathrm{~d} \\
\text { (b) }\end{array}$ & $\begin{array}{l}132,6 \text { de } \\
\text { (a) }\end{array}$ & $\begin{array}{c}37,0 \text { def } \\
\text { (a) }\end{array}$ & $\begin{array}{l}29,0 \text { abcd } \\
\text { (b) }\end{array}$ \\
\hline $\mathrm{F} 2$ & $\begin{array}{c}86,8 \mathrm{~d} \\
\text { (b) }\end{array}$ & $\begin{array}{c}114,1 \mathrm{f} \\
\text { (a) }\end{array}$ & $\begin{array}{c}30,5 \mathrm{fg} \\
\text { (a) }\end{array}$ & $\begin{array}{c}10,8 \mathrm{~g} \\
\text { (b) }\end{array}$ \\
\hline F3 & $\begin{array}{l}91,1 \mathrm{~cd} \\
\text { (b) }\end{array}$ & $\begin{array}{c}118,9 \text { ef } \\
\text { (a) }\end{array}$ & $\begin{array}{c}36,0 \text { def } \\
\text { (a) }\end{array}$ & $\begin{array}{c}19,4 \text { defg } \\
\text { (a) }\end{array}$ \\
\hline F4 & $\begin{array}{c}91,4 \mathrm{c} \\
\text { (b) }\end{array}$ & $\begin{array}{c}132,6 \text { de } \\
\text { (a) }\end{array}$ & $\begin{array}{c}52,4 \text { bc } \\
\text { (a) }\end{array}$ & $\begin{array}{l}32,3 \mathrm{ab} \\
\text { (b) }\end{array}$ \\
\hline H1 & $\begin{array}{l}49,7 \mathrm{~g} \\
\text { (b) }\end{array}$ & $\begin{array}{c}120,8 \text { ef } \\
\text { (a) }\end{array}$ & $\begin{array}{l}76,6 \mathrm{a} \\
\text { (a) }\end{array}$ & $\begin{array}{c}31,9 a b c \\
\text { (b) }\end{array}$ \\
\hline $\mathrm{H} 4$ & $\begin{array}{c}115,6 \mathrm{~b} \\
\text { (a) }\end{array}$ & $\begin{array}{c}122,1 \text { ef } \\
\text { (a) }\end{array}$ & $\begin{array}{l}21,0 \mathrm{~g} \\
\text { (a) }\end{array}$ & $\begin{array}{c}13,9 \mathrm{fg} \\
\text { (a) }\end{array}$ \\
\hline $\mathrm{L} 2$ & $\begin{array}{c}86,2 \mathrm{~d} \\
\text { (a) }\end{array}$ & $\begin{array}{c}110,0 \mathrm{f} \\
\text { (a) }\end{array}$ & $\begin{array}{c}37,6 \text { def } \\
\text { (a) }\end{array}$ & $\begin{array}{c}29,0 \text { abcd } \\
\text { (a) }\end{array}$ \\
\hline Inpago 8 & $\begin{array}{l}65,4 \mathrm{f} \\
\text { (b) }\end{array}$ & $\begin{array}{c}196,5 \mathrm{a} \\
\text { (a) }\end{array}$ & $\begin{array}{c}83,9 \text { a } \\
\text { (a) }\end{array}$ & $\begin{array}{c}26,6 \text { bcd } \\
\text { (b) }\end{array}$ \\
\hline P. Wangi & $\begin{array}{l}88,7 \mathrm{~d} \\
\text { (b) }\end{array}$ & $\begin{array}{c}165,4 \mathrm{~b} \\
\text { (a) }\end{array}$ & $\begin{array}{l}\text { Bcd bcd } \\
\text { (a) }\end{array}$ & $\begin{array}{l}14,5 \text { efg } \\
\text { (b) }\end{array}$ \\
\hline Gilirang & $\begin{array}{l}84,3 \text { de } \\
\text { (b) }\end{array}$ & $\begin{array}{c}144,3 \mathrm{c} \\
\text { (a) }\end{array}$ & $\begin{array}{c}54,3 \mathrm{~b} \\
\text { (a) }\end{array}$ & $\begin{array}{l}39,0 \text { a } \\
\text { (b) }\end{array}$ \\
\hline Ciherang & $\begin{array}{l}86,4 \mathrm{~d} \\
\text { (b) }\end{array}$ & $\begin{array}{c}130,0 \text { de } \\
\text { (a) }\end{array}$ & $\begin{array}{c}34,4 \text { ef } \\
\text { (a) }\end{array}$ & $\begin{array}{c}24,6 \text { bcde } \\
\text { (a) }\end{array}$ \\
\hline
\end{tabular}

Keterangan: Angka-angka yang diikuti huruf yang sama tanpa kurung pada kolom yang sama menunjukkan tidak berbeda nyata, dan angka-angka yang diikuti huruf yang sama dalam kurung pada baris yang sama menunjukkan tidak berbedanyata menurut uji BNT 5\%.

\section{Bobot 1000 butir Gabah dan Hasil Gabah tiap Rumpun}

Interaksi Galur dan Lingkungan terhadap bobot 1000 butir gabah (Tabel 6), terdapat satu galur padi baru dan dua varietas pembanding yang penampilannya stabil pada lahan kering atau gogo dan lahan sawah, yaitu galur F4, dan varietas Gilirang serta Ciherang. Nilai KK genotipe dan lingkungan pada variabel bobot 1000 butir gabah isi lebih besar dari 5\%, yaitu masing-masing 6,16\% dan 6,21\%, ini menunjukkan bahwa variabel bobot 1000 butir gabah isi dipengaruhi moleh faktor lingkungan. Kondisi ini sejalan dengan hasil penelitian Mahmud \& Purnomo (2014), yang menyatakan bahwa bobot 1000 butir gabah isi setiap genotipe sangat dipengaruhi oleh faktor lingkungan.

Interaksi galur dan lingkungan terhadap hasil gabah tiap rumpun menunjukkan bahwa terdapat tujuh galur padi baru yang penampilannya tidak berbeda nyata antara yang ditanam di lahan gogokering atau sebagai padi gogo dan dilahan basah atau sebagai padi sawah, yaitu galur B3, B4, F2, F3, H1, H4, dan L2. Galur-galur tersebut menunjukkan bahwa memiliki daya adaptasi yang baik walaupun ditanam pada lingkungan yang (Tabel 6). Hasil analisis statistik Koefisien Keragaman (KK) genotipe dan lingkungan pada variabel hasil gabah tiap rumpun menunjukkan angka yang lebih besar dari $21 \%$. Ini sebenarnya kendali 
faktor lingkungan lebih dominan, tetapi kenyataannya ada beberapa galur yang ternyata memiliki kemampuan adaptasi yang kuat, sehingga hasilnya tidak berbeda nyata antara yang ditanam di lahan sawah dengan yang di lahan kering atau gogo.

Tabel 6. Interaksi Galur dan Lingkungan terhadap bobot 1000 butir gabah dan hasil gabah tiap rumpun

\begin{tabular}{|c|c|c|c|c|}
\hline \multirow{2}{*}{ Galur } & \multicolumn{2}{|c|}{ bobot 1000 butir gabah $(\mathrm{g})$} & \multicolumn{2}{|c|}{ Hasil Gabah tiap Rumpun (g) } \\
\hline & Gogo & Sawah & Gogo & Sawah \\
\hline & $21,5 \mathrm{f}$ & $26,7 \mathrm{c}$ & $27,9 \mathrm{gh}$ & $63,6 \mathrm{bc}$ \\
\hline B2 & (b) & (a) & (b) & (a) \\
\hline & $21,7 \mathrm{f}$ & $28,9 \mathrm{~b}$ & 57,1 a & $62,1 \mathrm{bc}$ \\
\hline B3 & (b) & (a) & (a) & (a) \\
\hline & $25,0 \mathrm{bcd}$ & $30,5 \mathrm{ab}$ & $47,8 \mathrm{bc}$ & $47,5 \mathrm{e}$ \\
\hline B4 & (b) & (a) & (a) & (a) \\
\hline & $22,1 \mathrm{ef}$ & $29,5 \mathrm{ab}$ & $41,0 \mathrm{cde}$ & $60,3 \mathrm{bc}$ \\
\hline B7 & (b) & (a) & (b) & (a) \\
\hline & $23,4 \mathrm{de}$ & $25,0 \mathrm{~d}$ & $32,3 \mathrm{fgh}$ & $49,0 \mathrm{e}$ \\
\hline $\mathrm{F} 2$ & (a) & (a) & (a) & (a) \\
\hline & $21,8 \mathrm{f}$ & $28,9 \mathrm{~b}$ & $42,6 \mathrm{~cd}$ & $58,0 \mathrm{~cd}$ \\
\hline F3 & (b) & (a) & (a) & (a) \\
\hline & $27,7 \mathrm{a}$ & $30,1 \mathrm{ab}$ & 34,9 efg & $68,1 \mathrm{ab}$ \\
\hline F4 & (a) & (a) & (b) & (a) \\
\hline & $21,1 \mathrm{f}$ & $30,0 \mathrm{ab}$ & 18,9 hi & $34,9 \mathrm{f}$ \\
\hline H1 & (b) & (a) & (a) & (a) \\
\hline & $21,6 \mathrm{f}$ & $25,0 \mathrm{~d}$ & $53,5 \mathrm{ab}$ & $48,6 \mathrm{e}$ \\
\hline $\mathrm{H} 4$ & (b) & (a) & (a) & (a) \\
\hline & $25,9 \mathrm{~b}$ & $31,0 \mathrm{a}$ & $47,8 \mathrm{bc}$ & $54,5 \mathrm{de}$ \\
\hline L2 & (b) & (a) & (a) & (a) \\
\hline & $24,1 \mathrm{~cd}$ & $26,7 \mathrm{c}$ & $25,1 \mathrm{hi}$ & $60,8 \mathrm{bcc}$ \\
\hline Inpago 8 & (b) & (a) & (b) & (a) \\
\hline & $25,7 \mathrm{bc}$ & $28,9 \mathrm{~b}$ & $52,0 \mathrm{ab}$ & $73,4 \mathrm{a}$ \\
\hline P. Wangi & (b) & (a) & (b) & (a) \\
\hline & $26,1 \mathrm{~b}$ & $26,7 \mathrm{c}$ & $33,4 \mathrm{fg}$ & $56,9 \mathrm{~cd}$ \\
\hline Gilirang & (a) & (a) & (b) & (a) \\
\hline Ciherang & $\begin{array}{c}24,1 \mathrm{~cd} \\
\text { (a) }\end{array}$ & $\begin{array}{l}26,1 \mathrm{~cd} \\
\text { (a) }\end{array}$ & $\begin{array}{c}36,1 \mathrm{def} \\
\text { (b) }\end{array}$ & $\begin{array}{c}58,6 \mathrm{~cd} \\
\text { (a) }\end{array}$ \\
\hline
\end{tabular}

Keterangan: Angka-angka yang diikuti huruf yang sama tanpa kurung pada kolom yang sama menunjukkan tidak berbeda nyata, dan angka-angka yang diikuti huruf yang sama dalam kurung pada baris yang sama menunjukkan tidak berbedanyata menurut uji BNT 5\%.

Interaksi Galur dan Lingkungan terhadap hasil gabah tiap hektar (Tabel 7), terdapat tujuh galur padi baru yang penampilannya stabil (tidak berbeda nyata) antara yang ditanam di lahan gogo dan di lahan basah atau sebagai padi sawah. Ke tujuh galur tersebut yaitu B3, B4, F2, F3, H1, H4, dan L2. Tiga galur lain, dan empat varietas pembanding menunjukkan penampilan yang tidak cocok (adaptasinya kurang baik). Ini menujukkan bahwa ke tujuh galur padi baru yang diuji memiliki kemampuan beradaptasi yang baik walaupun ditanam pada kondisi lingkungan yang berbeda, yaitu sebagai padi gogo (upland rice) dan sebagai padi sawah (law land rice).

Tabel 7. Interaksi Galur dan Lingkungan terhadap hasil gabah tiap hektar 


\begin{tabular}{|c|c|c|}
\hline \multirow{2}{*}{ Galur } & \multicolumn{2}{|c|}{ Hasil Gabah tiap Hektar (ton) } \\
\hline & Gogo & Sawah \\
\hline B2 & $\begin{array}{l}4,47 \mathrm{gh} \\
\text { (b) }\end{array}$ & $\begin{array}{c}10,17 \text { bc } \\
\text { (a) }\end{array}$ \\
\hline & 9,14 a & $9,94 \mathrm{bc}$ \\
\hline B3 & (a) & (a) \\
\hline & $7,65 \mathrm{bc}$ & $7,61 \mathrm{e}$ \\
\hline B4 & (a) & (a) \\
\hline & 6,57 cde & $9,65 \mathrm{bcd}$ \\
\hline B7 & (b) & (a) \\
\hline & $5,16 \mathrm{fgh}$ & $7,84 \mathrm{e}$ \\
\hline F2 & (a) & (a) \\
\hline & $6,81 \mathrm{~cd}$ & $9,28 \mathrm{~cd}$ \\
\hline F3 & (a) & (a) \\
\hline & $5,58 \mathrm{efg}$ & $10,90 \mathrm{ab}$ \\
\hline F4 & (b) & (a) \\
\hline & $3,03 \mathrm{i}$ & $5,58 \mathrm{f}$ \\
\hline H1 & (a) & (a) \\
\hline & $8,57 \mathrm{ab}$ & 7,77 e \\
\hline $\mathrm{H} 4$ & (a) & (a) \\
\hline & $7,64 \mathrm{bc}$ & $8,71 \mathrm{de}$ \\
\hline L2 & (a) & (a) \\
\hline Inpago 8 & $\begin{array}{l}4,02 \mathrm{hi} \\
\text { (b) }\end{array}$ & $\begin{array}{c}9,73 \text { bcd } \\
\text { (a) }\end{array}$ \\
\hline P. Wangi & $\begin{array}{l}8,32 \mathrm{ab} \\
\text { (b) }\end{array}$ & $\begin{array}{c}11,75 \mathrm{a} \\
\text { (a) }\end{array}$ \\
\hline & $5,34 \mathrm{fg}$ & $9,10 \mathrm{~cd}$ \\
\hline Gilirang & (b) & (a) \\
\hline Ciherang & $\begin{array}{c}5,78 \mathrm{def} \\
\text { (b) }\end{array}$ & $\begin{array}{l}9,37 \mathrm{~cd} \\
\text { (a) }\end{array}$ \\
\hline
\end{tabular}

Keterangan: Angka-angka yang diikuti huruf yang sama tanpa kurung pada kolom yang sama menunjukkan tidak berbeda nyata, dan angka-angka yang diikuti huruf yang sama dalam kurung pada baris yang sama menunjukkan tidak berbedanyata menurut uji BNT 5\%.

Berdasarkan nilai koefisien keragaman (KK) untuk variabel jumlah tunas produktif, jumlah gabah tiap malai, jumlah gabah isi tiap malai, jumlah gabah hampa tiap malai, hasil gabah tiap rumpun, dan konversi hasil gabah tiap hektar (Tabel 1) menunjukkan angka yang tinggi, yaitu antara 15,64\% - 31,95\%. Koefisien keragaman yang lebih kecil dari 5\% dianggap bahwa fenotipe merupakan ekspresi genotipe $(\mathrm{F}=\mathrm{G}+\mathrm{I}$; $\mathrm{I}=$ 0,(Hallauer \& Miranda, 1981)). Koefisien keragaman yang lebih kecil atau sama dengan 5\% menunjukkan fenotipik sama dengan genotipik $(\mathrm{F}=\mathrm{G})$. Koefisien keragaman yang melampaui $10 \%$ menunjukkan bahwa pengaruh lingkungan atas kinerja fenotipe yang tidak dapat diabaikan.

\section{KESIMPULAN [DAN SARAN (Optional)]}

Hasil analisis data yang diuji secara statistik terhadap variabel pertumbuhan dan komponen hasil yang diamati, galur padi yang ditanam di dua lingkungan yang berbeda yaitu pada lingkungan awah dan gogo,dapat disimpulkan sebagai berikut: Kemampuan beradaptasi dari beberapa galur yang diuji pada lingkungan tumbuh yang berbeda memberikaan respon yang berbeda-beda, ada yang beradaptasi baik dan ada yang kurang baik. Terdapat tujuh galur padi baru yaitu galur B3, B4, F2, F3, H1, H4, dan L2 penampilan potensi hasilnya tidak berbeda nyata antara yang ditanam di lahan kering (padi gogo) dan dilahan basah (sebagai padi sawah). Ini menunjukkan bahwa galur-galur tersebut memiliki adaptasi yang 
baik pada kedua lingkungan tersebut. Tiga galur baru dan empat varietas pembanding menunjukkan adaptasi yang kurang baik jika ditanam sebagai padi gogo.

\section{DAFTAR PUSTAKA}

Abdullah, B. 2006. Perakitan dan Pengembangan Varietas Padi Tipe Baru. Padi Buku ed. Balai Besar Penelitian Tanaman Padi Badan Penelitian dan Pengembangan Pertanian.

BPS 2015. Berita Resmi Statistik No. 55/07/21/Th.X, 01 Juli 2015. Badan Pusat Statistik Provinsi Kepulauan Riau.

Budiono, S., Fajriani \& Widaryanto, E. 2014. Uji Potensi Hasil 12 Galur Padi (Oryza sativa L.) Hibrida Pada Dataran Medium dengan Ketinggian 505 mdpl. Jurnal Produksi Tanaman, 2(4): 275-281.

Fatimaturrohmah, S., Rumanti, I.A., Soegianto, A. \& Damanhuri 2016. Uji Daya Hasil Lanjutan Beberapa Genotipe Padi (Oryza sativa L.) Hibrida di Dataran Medium.

Hallauer, A. \& Miranda, F.. 1981. Quantitative Genetic in Maize Breeding. Iowa State Univ. Iowa State ed. Press. Ames, IO. Press.Ames,IO.

Hersanti, L. \& Mugiono 2006. Perbaikan Daya Hasil Varietas Padi Cimelati Melalui Teknik Mutasi. Risalah Seminar Ilmiah Aplikasi Isotop dan Radiasi. Pusat Aplikasi Teknologi Isotop dan Radisi BATAN.

Kartahadimaja, J., Syuriani, E.E. \& Apriani, M. 2016. Potensi Kuantitatif dan Kualitatif 10 galur Unggul Baru Padi Jenis Pandan Wangi. Jurnal Penelitian Pertanian Terapan, 16(2): 109-113.

Mahmud, Y. \& Purnomo, S.. 2014. Keragaan Agronomis Beberapa Varietas Unggul Baru Tanaman Padi (Oryza sativa L.) Pada Model Pengelolaan Tanaman Terpadu. Jurnal Ilmiah Solusi, 1: 1-10.

Makarim, A.K. \& Suhartatik, E. 2009. Morfologi dan Fisiologi Tanaman Padi. Balai Penelitian Tanaman Padi.

Rahayu, S., Dewi, A.K., Yulidar, Wirnas, D. \& Aswidinnoor, H. 2013. Analisis Stabilitas dan Adaptabilitas Beberapa Galur Padi Dataran Tinggi Hasil Mutasi Induksi. A Scientific Journal for The Applications of Isotopes and Radiation, 9(2): 81-90.

Santosa, I.G.N., Adnyana, G.M. \& Dinata, I.K.K. 2011. Dampak Alih Fungsi Lahan Sawah Terhadap Ketahanan Pangan Beras. Bengkulu: Prosiding Seminar Nasional Budidaya Pertanian, hal.1-11.

Singh, R.K. \& Chaudhary, B.. 1979. Biometrical Methods in Quantitative Genetical Analysis. New Delhi: Kalyani Publishers.

Sobir 2013. Optimalisasi Lahan Suboptimal bagi Penguatan Ketahanan Pangan Indonesia. Palembang: Prosiding Seminar Nasional Lahan Suboptimal "Intensifikasi Pengelolaan Lahan Suboptimal dalam Rangka Mendukung Kemandirian Pangan Nasional, hal.23-27.

Suryana, A., Mardianto, S., Kariyasa, K. \& Wardana, I.. 2009. Kedudukan Padi Dalam Perekonomian Indonesia. 